\title{
DAKTILITAS
}

Jurnal Teknik Sipil Universitas Tulungagung

Journal Home Page : https://journal.unita.ac.id/index.php/daktilitas

Volume 1, Nomor 1, Tahun 2021

\section{PERENCANAAN ULANG STRUKTUR ATAS MENGGUNAKAN KONSEP \\ TAHAN GEMPA DENGAN SISTEM STRONG COLUMN WEAK BEAM PADA BANGUNAN RUSUNAWA KOTA KEDIRI}

\section{THE SUPER STRUCTURE REDESIGN OF FLATS CONSTRUCTION KEDIRI USING EARTHQUAKE RESISTANCE CONCEPT WITH STRONG COLUMN WEAK BEAM SYSTEM}

\author{
Aditya Purnama, S.ST., M.T. \\ Program Studi Teknik Sipil Universitas Tulungagung \\ Jalan Kimangunsarkoro Beji, Kec. Boyolangu, Kab. Tulungagung 66233 \\ Email:purnamaaditya126@gmail.com
}

\begin{abstract}
Geologically, Indonesia is located in the Pacific Ring of Fire, which is a series of the most active volcanoes in the world that stretches along the Pacific plate Because of this, geological disasters often hit Indonesia, both from earthquakes and volcanic eruptions Therefore, it is necessary to redesign the superstructure using the concept of earthquake resistance with a strong columnweak beam system in the Rusunawa building in the Kediri city.

Redesign of rusunawa building in the Kediri city using a special moment reinforced concrete frame system that refers to the SNI 1726:2012 earthquake regulation and applying a strong column weak beam system so that the building can withstand an earthquake well.

The result of this redesign is that the building is able to withstand earthquake loads according to the earthquake regulations of SNI 1726:2012 and applies the strong column weak beam system properly, by making changes to the beam and column structure design in the Rusunawa building in the Kediri city.
\end{abstract}

Keywords: earthquake, earthquake resistance, SNI 1726:2012, strong column weak beam

\section{ABSTRAK}

Secara geologis, Indonesia berada pada Daerah Cincin Api Pasifik (Pacifik Ring of Fire), yaitu rangkaian gunung berapi paling aktif di dunia yang membentang di sepanjang lempeng pasifik. Inilah penyebab bencana geologis sering melanda Indonesia, baik dari gempa bumi maupun letusan gunung berapi. Maka dari itu perlunya melakukan perencanaan ulang struktur atas menggunakan konsep tahan gempa dengan sistem strong colum weak beam pada bangunan rusunawa kota kediri.

Perencanaan ulang bangunan rusunawa kota kediri yang menggunakan sistem rangka beton bertulang pemikul momen khusus yang mengacu pada peraturan gempa SNI 1726:2012 dan menerapkan sistem strong column weak beam agar bangunan gedung mampu bertahan dengan baik ketika terjadi gempa bumi.

Hasil dari perencanaan ulang ini bangunan mampu menahan beban gempa sesuai peraturan gempa SNI 1726:2012 dan menerapkan sistem strong column weak beam dengan baik, dengan melakukan perubahan desain struktur balok dan kolom pada bangunan rusunawa kota kediri.

Kata kunci:gempa bumi, tahan gempa, SNI 1726:2012, strong column weak beam

\section{PENDAHULUAN}

Secara geologis, Indonesia berada pada Daerah Cincin Api Pasifik (Pacifik Ring of Fire), yaitu rangkaian gunung berapi paling aktif di dunia yang membentang di sepanjang lempeng pasifik. Indonesia juga berada pada posisi pertemuan antara tiga lempeng utama dunia, yaitu Iempeng Eurasia, Iempeng Indo-Australia, dan Iempeng Pasifik. Inilah penyebab bencana geologis sering melanda Indonesia, baik dari gempa bumi maupun letusan gunung berapi.

Gambaran singkat tentang bencana tersebut menjelaskan bahwa Indonesia memiliki potensi bencana alam yang cukup tinggi sehingga diperlukan upaya antisipasi berupa 
pemenuhan kaidah-kaidah perencanaan/pelaksanaan sistem struktur tahan gempa pada bangunan gedung.

Dengan dipenuhinya kaidah-kaidah perencanaan bangunan sesuai dengan standar yang ditentukan, maka semakin banyak peluang masyarakat dapat meminimalkan kerugian yang diakibatkan terjadinya bencana alam gempa bumi.

Untuk itu, kami akan membahas tentang Perencanaan Ulang Struktur Atas Menggunakan Konsep Tahan Gempa dengan Sistem Strong Colum Weak Beam pada Bangunan Rusunawa Kota Kediri.

Berdasarkan pada latar belakang di atas maka dirumuskan permasalahan sebagai berikut: bagaimana analisis struktur atas menggunakan konsep tahan gempa pada Bangunan Rusunawa Kota Kediri, bagaimana perencanaan beton bertulang dengan sistem strong column weak beam pada Bangunan Rusunawa Kota Kediri, bagaimana perbandingan hasil perencaan beton bertulang terhadap kondisi existing pada Bangunan Rusunawa Kota Kediri.

Untuk mendapatkan hasil yang baik, maka diperlukan batasan-batasan sebagai berikut: peraturan pembebanan menggunakan SNI 1727:2013 Beban Minimum untuk Perencanaan Bangunan Gedung dan Struktur lain, peraturan gempa menggunakan SNI 1726:2012 Tata Cara Perencanaan Ketahanan Gempa untuk Struktur Bangunan Gedung dan Non Gedung, perencanaan beton bertulang menggunakan SNI 2847:2013 Persyaratan Beton Struktural untuk Bangunan Gedung yang mengacu pada ACI 318-11 Building Code Requirements for Structural Concrete, analisa statika menggunakan modeI 3D dengan program Midas Gen 2019, perencanaan beton bertulang membahas pada perencanaan balok dan kolom.

Tujuan dari penelitian ini adalah untuk: mengetahui analisis struktur atas menggunakan konsep tahan gempa pada Bangunan Rusunawa Kota Kediri, mengetahui perencanaan beton bertulang dengan sistem strong column weak beam pada Bangunan Rusunawa Kota Kediri, mengetahui perbandingan hasil perencaan beton bertulang terhadap kondisi existing pada Bangunan Rusunawa Kota Kediri.

\section{METODE PENELITIAN}

Tahapan pada penelitian ini bertujuan untuk memberikan gambaran mengenai langkahlangkah penelitian secara sistematis supaya proses penelitian dapat berjalan dengan teratur dan sesuai dengan peraturan struktur beton bertulang SNI 2847:2013 dan peraturan gempa SNI 1726:2012.

Perencanaan ulang pada penelitian ini tulangan utama yang dipakai direncanakan menggunakan tulangan deform yaitu tulangan yang memiliki bentuk permukaan tidak halus

(bergerigi dan berulir) yang diharapkan mampu memiliki daya Iekat yang baik terhadap beton bila dibandingkan dengan tulangan yang polos. Mutu bahan yang digunakan pada perencanaan ini antara lain: mutu beton (fc') menggunakan K350 (29.1 MPa), mutu tulangan polos (fy) menggunakan $240 \mathrm{MPa}$, mutu tulangan ulir (fy) menggunakan 390 MPa.

Pembebanan yang diperhitungkan pada perencanaan Bangunan Rusunawa Kota Kediri secara garis besar adalah beban mati, beban hidup, beban angin, dan beban gempa. Perencanaan ini meninjau pengaruh gempa dengan dua metode untuk kemudian dimasukkan dalam kombinasi pembebanan dan dicari kondisi paling kritis.

Metode tersebut yang pertama ialah beban gempa ditinjau sebagai beban statik, sehingga digunakan modeI perhitunga beban gempa secara statik ekivalen, cara ini dapat dilakukan karena bentuk bangunan beraturan dan simetris.

Metode yang kedua ialah beban gempa ditinjau sebagai beban dinamis, dimana metode ini digunakan untuk mengetahui perilaku bangunan ketika sebuah gempa terjadi, karena metode ini akan memberikan beban gempa secara dinamis baik arah $\mathrm{X}$, Y, bahkan putaran, dengan metode ini perilaku bagnunan ketika menerima beban gempa akan lebih bisa untuk diketahui. Untuk mendapatkan nilai respons spectrum, faktor angka tertentu, dan peta gempa pada perenncanaan ini menggunakan peraturan gempa SNI 1726:2012. 
Perhitungan analisis untuk mendapatkan besarnya gaya-gaya dalam yang bekerja pada struktur bangunan digunakan program Midas Gen 2019. Prinsip dasar yang digunakan untuk melakukan perencanaan desain penampang beton bertulang pada Bangunan Rusunawa Kota Kediri adalah dengan menggunakan metode kekuatan (strength design method) yaitu : $\mathrm{U} \leq \varphi \mathrm{Rn}$ dan dan sistem strong column weak beam dimana kapasitas kolom harus lebih besar dari kapasits balok $\left(\varphi \mathrm{Rn}_{\mathrm{C}}>\varphi \mathrm{Rn}_{\mathrm{B}}\right)$. Hasil perhitungan perencanaan yang telah dikontroI perhitungannya akan dituangkan ke daIam bentuk gambar detail penulangan. Bagan alur perencanaan diperlihatkan pada Gambar 1.

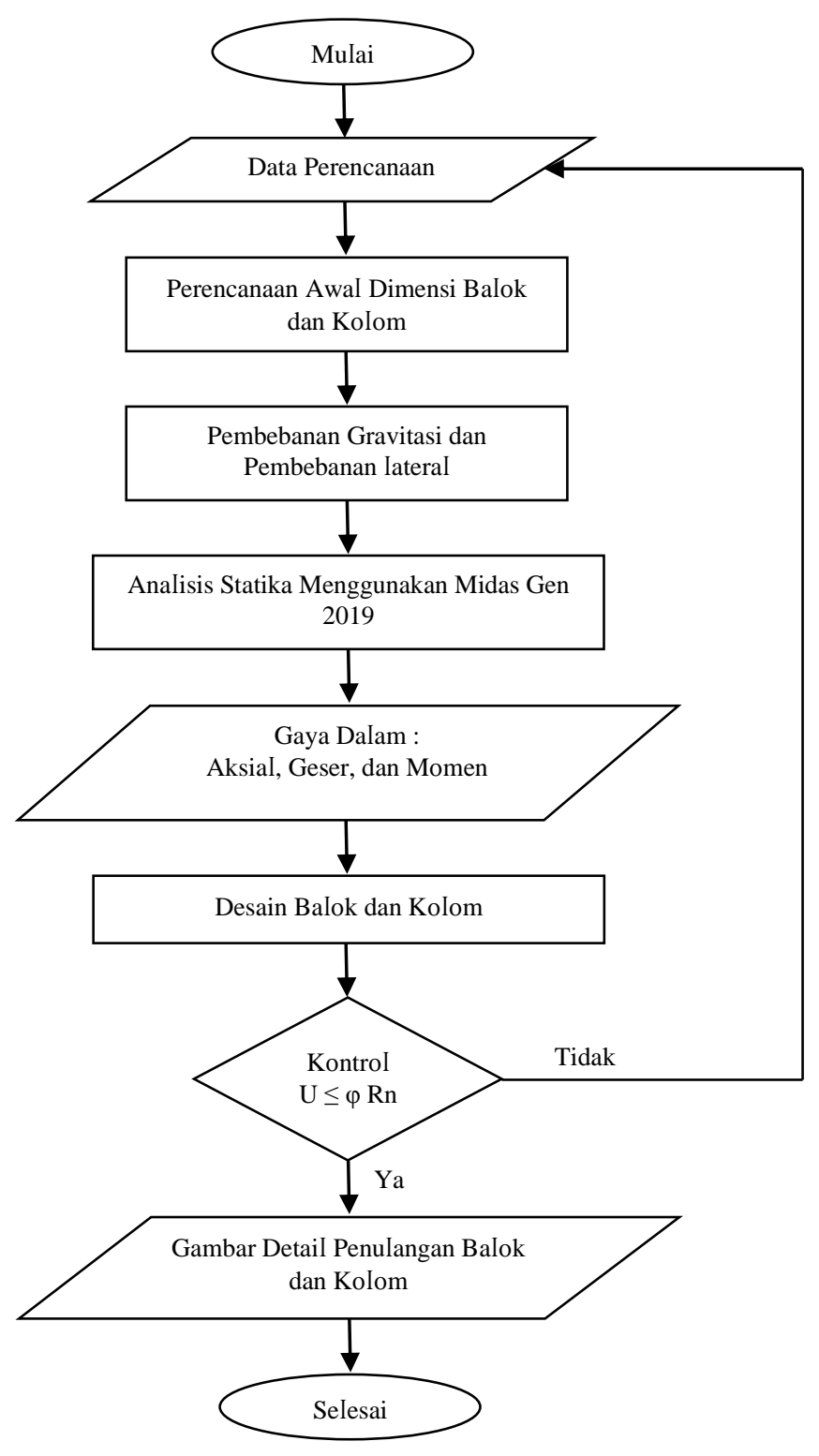

Gambar 1. Diagram alur perencanaan

\section{Prinsip Perencanaan Struktur Tahan Gempa}

Praja (2020) menyatakan, perencanakan sebuah bangunan baik itu yang difungsikan untuk kegiatan bisnis, tempat tinggal, maupun fungsi khusus, harus direncanakan mengikuti standar yang berlaku. Perencanaan ini bertujuan untuk memperkecil risiko kegagalan pada struktur bangunan, mengingat letak Indonesia yang berada di Kawasan Cincin Api Pasifik (Pasifik Ring of Fire). 
Beberapa prinsip perencanaan bangunan tahan gempa yang harus diperhatikan, antara Iain:

1. Sistem struktur yang digunakan perencanaan harus sesuai dengan tingkat kerawanan (resiko gempa) dimana bangunan tersebut didirikan.

2. Pendetailan penulangan, sambungan-sambungan, unsur-unsur bangunan harus terikat secara efektif menjadi satu kesatuan dan sesuai standar yang telah ditentukan.

3. Material beton dan baja harus memenuhi syarat peraturan bangunan tahan gempa.

4. Unsur-unsur arsitektural yang memiliki massa yang besar harus terikat dengan kuat pada sistem struktur utama.

5. Karakteristik suatu bangunan sangat berpengaruh terhadap gaya gempa yang akan diterima bangunan. Bentuk denah bangunan yang simetris dan tidak terlalu panjang dapat mengurangi beban gempa yang diterima bangunan, selain itu massa bangunan diupayakan dibuat seringan mungkin.

\section{Konsep Desain Bangunan Tahan Gempa.}

Kriteria bangunan tahan gempa disyaratkan dapat menahan beban gempa 2500 tahunan sesuai peraturan gempa SNI 1726:2012. Selain itu material beton dan baja tulangan juga sangat mempengaruhi kualitas struktur yang dihasilkan. Salah satu parameter beton yang sangat berpengaruh adalah kuat tekan beton.

Purwono (2005) Menyatakan dalam perencanaan struktur bangunan tahan gempa, diperlukan standar dan peraturan-peraturan dalam merencanakan bangunan untuk menjamin keselamatan penghuni terhadap gempa besar yang mungkin terjadi serta menghindari dan meminimalkan kerusakan struktur bangunan dan korban jiwa terhadap gempa bumi yang sering terjadi. oleh karena itu, struktur bangunan tahan gempa harus memiliki kekuatan, kekakuan, dan stabilitas yang cukup untuk mencegah bangunan mengalami keruntuhan. Filosofi dan konsep dasar perencanaan bangunan tahan gempa adalah:

1. Pada saat terjadi gempa ringan (Minor Shaking), struktur bangunan dan fungsi bangunan harus dapat tetap berjalan (servicable), maka dari itu struktur harus kuat dan tidak ada kerusakan baik pada elemen struktural dan elemen nonstruktural bangunan.

2. Pada saat terjadi gempa sedang (Moderate Shaking), struktur diperbolehkan mengalami kerusakan pada elemen nonstruktural bagnunan, namun tidak diperbolehkan terjadi kerusakan pada elemen struktural bangunan.

3. Pada saat terjadi gempa besar (Strong Shaking), diperbolehkan terjadi kerusakan pada elemen struktural dan nonstruktural, akan tetapi tidak boleh sampai menyebabkan bangunan runtuh, kalaupun bangunan runtuh harus memberikan waktu yang cukup pada penghuni bangunan tersebut untuk menyelamatkan diri sehingga tidak ada korban jiwa atau dapat meminimalkan jumlah korban jiwa.

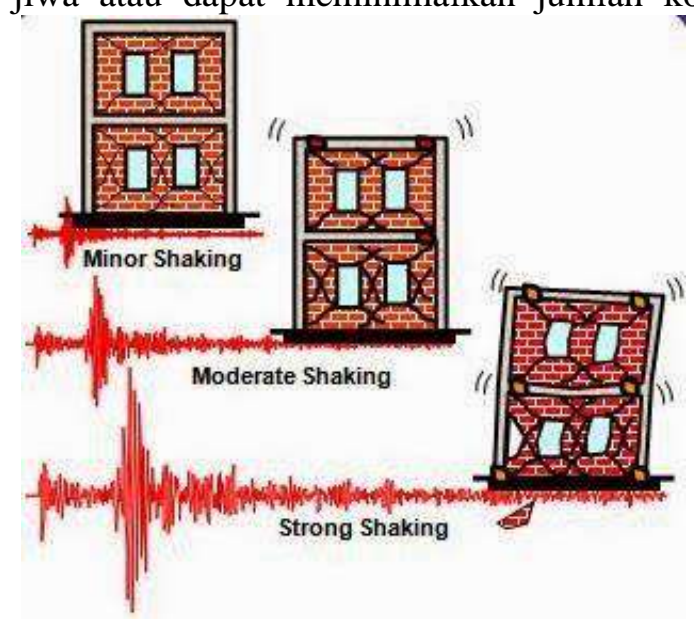

Gambar 2. Filosofi dan Konsep Dasar Perencanaan Bangunan Tahan Gempa (Sumber : Akbar 2019) 
Struktur yang direncanakan diharapkan mampu bertahan oleh beban bolak-balik yang diakibatkan oleh gempa memasuki perilaku inelastik tanpa mengurangi kekuatan yang berarti. Maka dari itu, selisih energi beban gempa harus mampu disebarkan dan diserap oleh struktur yang bersangkutan dalam bentuk kemampuan berdeformasi secara inelastis. Kemampuan ini yang disebut sebagai kemampuan daktilitas struktur.

Pengertian daktilitas secara umum dapat diartikan sebagai kemampuan suatu elemen struktur untuk berdeformasi baik rotasi maupun translasi pada saat menyerap energi dari Iuar sistem tanpa mengalami kegagalan/putus. Supaya lebih jelas, daktilitas akan dijelaskan pada uraian di bawah ini:

1. Daktilitas Material

Kemampuan suatu material baik baja, beton, maupun kayu dalam mengembangkan regangannya dari pertama kali leleh hingga akhirnya putus merupakan pengertian dari daktilitas material. Daktilitas bisa juga kita artikan dengan seberapa plastis material tersebut. Semakin panjang suatu material dapat mengalami regangan setelah melewati batas elastisitasnya (plastis), maka semakin daktail material tersebut.

2. Daktilitas Struktur

Daktilitas struktur dapat diartikan sebagai kemampuan suatu struktur gedung untuk mengalami simpangan pasca-elastik yang besar secara berulang kali dan bolakbalik akibat beban gempa yang menyebabkan terjadinya pelelehan pertama, sambiI mempertahankan kekuatan dan kekakuan yang cukup, sehingga struktur gedung tersebut tetap dapat berdiri, walaupun bagnunan tersebut sudah berada dalam kondisi diambang keruntuhan.

Daktilitas inilah yang merupakan dasar dari perencanaan bangunan tahan gempa. lebih tepatnya adalah, sambungan balok ke kolom inilah yang direncanakan sebagai elemen struktur yang mengalami Ieleh (kondisi plastis) ketika struktur balok menyerap energi gempa. Maka dari itu struktur kolom harus direncanakan lebih kuata darioada struktur balok. Semakin daktail suatu struktur, maka kekuatan ultimate dari struktur tersebut semakin tinggi dan kemampuan berdeformasinya semakin besar.

Namun yang perlu diperhatikan ialah, seberapa besar kemampuan struktur tersebut dalam memikuI beban tambahan setelah mengalami leleh pertama kali dan akhirnya putus. Struktur tahan gempa yang baik adalah struktur dengan kemampuan daktilitas yang tinggi agar dapat memberikan tanda-tanda kerusakan pada bangunan ketika gempa terjadi sehingga tersedia banyak waktu untuk menyelamatkan diri sebelum akhirnya keruntuhan terjadi. Maka dari itulah struktur balok direncanakan agar mengalami leleh terlebih dahulu daripada kolom sesuai konsep Strong Column and Weak Beam (SCWB).

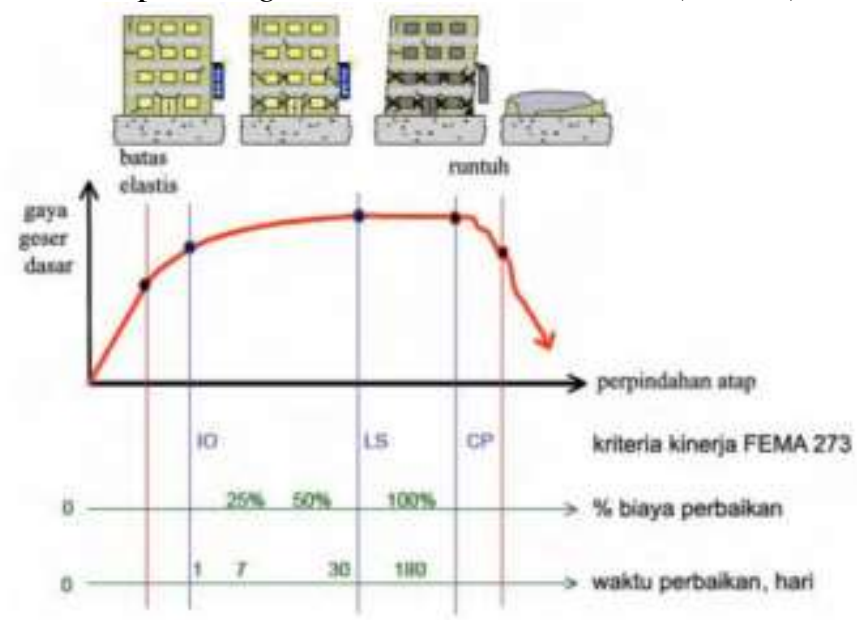

Gambar 3. Kemampuan daktilitas struktur bangunan dalam menerima beban gempa (Sumber : FEMA 273, 1997) 
Metode Penerapan Sistem Strong Column Weak Beam (SCWB) pada Struktur Bangunan.

Praja (2020) menyatakan, terdapat beberapa metode penerapan sistem SCWB (Strong Column and Weak Beam) pada struktur bangunan. Adapun metode yang dapat digunakan adalah sebagai berikut.

Pertama, dalam perencanaan struktur bangunan gedung, dimensi kolom harus direncanakan lebih besar perbandingannya terhadap dimensi balok. Metode ini merupakan prinsip dasar perencanaan mengenai estimasi dimensi dalam preliminary analysis.

Kedua, desain kapasitas kolom harus lebih besar dari kapasitas balok, hal ini akan membuat bangunan tetap berdiri meskipun balok sudah mengalami sendi plastis sehingga penghuni masih memiliki waktu yang cukup untuk menyelamatkan diri meskipun gempa besar terjadi.

\section{HASI DAN PEMBAHASAN}

\section{Data Perencanaan Awa dan Dimensi Struktur}

Perencanaan struktur bangunan gedung harus kuat dan aman, selain itu juga harus berdasarkan berdasarkan kebutuhan tata ruang dan desain secara arsitektural. HaI ini dilakukan supaya antara elemen struktur yang direncanakan dan fungsinya bisa sesuai. Oleh karena itu dimensi setiap elemen struktur yang ditaksir harus sama dengan kebutuhan desain bangunan tersebut.

- Dimensi Balok

$\begin{array}{ll}\text { Balok B1 } & =30 / 55 \mathrm{~cm} \\ \text { Balok B2 } & =35 / 45 \mathrm{~cm} \\ \text { Balok B3 } & =35 / 45 \mathrm{~cm} \\ \text { Balok B4 } & =25 / 45 \mathrm{~cm} \\ \text { Balok B5 } & =25 / 45 \mathrm{~cm} \\ \text { Balok B5 } & =25 / 45 \mathrm{~cm} \\ \text { Balok B6 } & =30 / 60 \mathrm{~cm} \\ \text { Balok CG } & =30 / 45 \mathrm{~cm} \\ \text { Balok BC } & =20 / 35 \mathrm{~cm} \\ \text { Balok RB1 } & =25 / 40 \mathrm{~cm} \\ \text { Balok RB2 } & =25 / 40 \mathrm{~cm} \\ \text { Balok RB3 } & =15 / 30 \mathrm{~cm} \\ \text { Balok BI } & =15 / 50 \mathrm{~cm}\end{array}$

- Dimensi Kolom

Kolom K1 $=40 / 55 \mathrm{~cm}$

Kolom K2 $=40 / 55 \mathrm{~cm}$

Kolom K3 $=40 / 55 \mathrm{~cm}$

Kolom K4 $=30 / 50 \mathrm{~cm}$

Kolom KP2 $=25 / 25 \mathrm{~cm}$

\section{Perhitungan Response Spectrum Design}

Berdasarkan peraturan gempa SNI 1726:2012 nilai respone spectrum design gempa tidak Iagi mengikuti peraturan Iama pada SNI 1726:2002, sehingga besaran nilainya harus dicari terlebih dahulu. Tahapan perhitungan untuk mendapat nilai respons spectrum design gempa adalah sebagai berikut:

a. Mencari parameter spektrum respon percepatan pada periode pendek $\left(S_{\mathrm{ms}}\right)$ dan periode 1 detik $\left(\mathrm{S}_{\mathrm{m} 1}\right)$, dengan asumsi nilai $\mathrm{F}_{\mathrm{a}}$ dan $\mathrm{F}_{\mathrm{v}}$ diambil dari kelas situs $\mathrm{SE}$.

$\mathrm{S}_{\mathrm{ms}}=\mathrm{F}_{\mathrm{a}} \cdot \mathrm{S}_{\mathrm{s}}=0,9 \cdot 1=0,9$

$\mathrm{S}_{\mathrm{m} 1}=\mathrm{F}_{\mathrm{v}} \cdot \mathrm{S}_{1}=2,4.0,4=0,96$

b. Menghitung parameter percepatan desain spektrum respon untuk periode pendek, $S_{d s}$ dan periode 1 detik $\left(\mathrm{S}_{\mathrm{d} 1}\right)$.

$\mathrm{S}_{\mathrm{ds}}=2 / 3 . \mathrm{S}_{\mathrm{ms}}=2 / 3 \cdot 0,9=0,6$

$\mathrm{S}_{\mathrm{d} 1}=2 / 3 \cdot \mathrm{S}_{\mathrm{m} 1}=2 / 3 \cdot 0,96=0,64$ 
c. $\mathrm{I}_{\mathrm{e}}$ digunakan 1 karena termasuk bangunan apartemen dengan faktor resiko keutamaan gempa kategori II.

d. $\mathrm{R}$ digunakan 8 karena sistem rangka pemikul momen yang digunakan menggunakan rangka beton bertulang pemikul momen khusus.

e. Membuat desain spektrum respon

1. Untuk membuat periode yang lebih kecil dari $T_{0}\left(T<T_{0}\right)$, nilai $S_{a}$ menggunakan persamaan berikut:

$$
S_{a}=S_{d s}\left(0,4+0,6 \frac{T}{T_{0}}\right)
$$

2. Untuk periode lebih besar dari atau sama dengan $T_{0}$ dan lebih kecil dari atau sama dengan $T_{S}\left(T_{0} \leq T \leq T_{S}\right)$, spektrum respons percepatan desain $S_{a}$ sama dengan $S_{d s}$.

3. Untuk periode lebih besar dari $\mathrm{T}_{\mathrm{S}}$, desain spektrum respon percepatan $\mathrm{S}_{\mathrm{a}}$ diambil menggunakan persamaan:

$$
S_{a}=\frac{S_{d 1}}{T} ; T_{0}=0,2 \frac{S_{d 1}}{S_{d s}} ; \quad T_{S}=\frac{S_{d 1}}{S_{d s}}
$$

Desain spektrum respon pada Bangunan Rusunawa Kota Kediri dapat dilihat pada gambar 4 berikut ini:

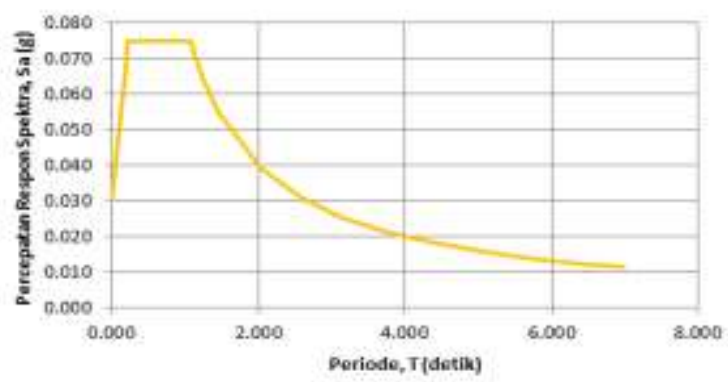

\section{Beban Geser Dasar Seismik Statik Ekivalen}

Gambar 4. Desain spektrum respon pada Bangunan Rusunawa Kota Kediri

Perhitungan beban geser dasar seismik dilakukan dengan melakukan kombinasi pada empat arah utama, yaitu: arah X positif (EI-XP), arah X negatif (EI-XN), arah Y positif (EI-YP), dan arah $Y$ negatif (El-YN). Setiap pembebanan gempa arah utama harus dianggap efektif $100 \%$ dan harus dianggap terjadi bersamaan pembebanan gempa dalam arah tegak Iurus arah utama dengan pengaruh efektifitas $30 \%$.

Perhitungan beban geser dasar seismik pada Bangunan Rusunawa Kota Kediri dilakukan menggunakan program komputer Midas Gen 2019 yang menggunakan standar IBC 2009 yang menupakan acuan dari SNI 1726:2012 Tata Cara Perencanaan Ketahanan Gempa untuk Struktur Bangunan Gedung dan Non Gedung. Adapun perhitungan beban geser dasar sismik pada Bangunan Rusunawa Kota Kediri akan disajikan dalam bentuk gambar berikut.

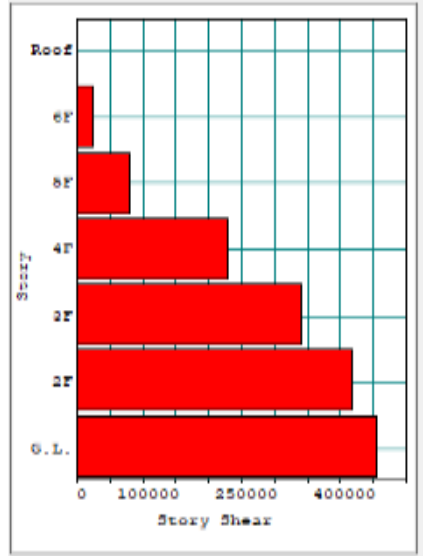

Gambar 5. Beban geser dasar seismik (EI-XP), kg

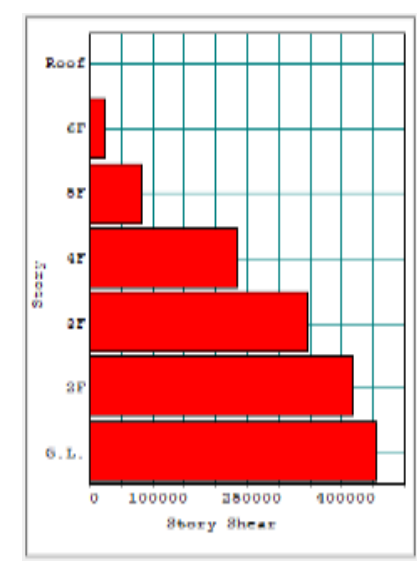

Gambar 6. Beban geser dasar seismik (EI-YP), $\mathrm{kg}$ 


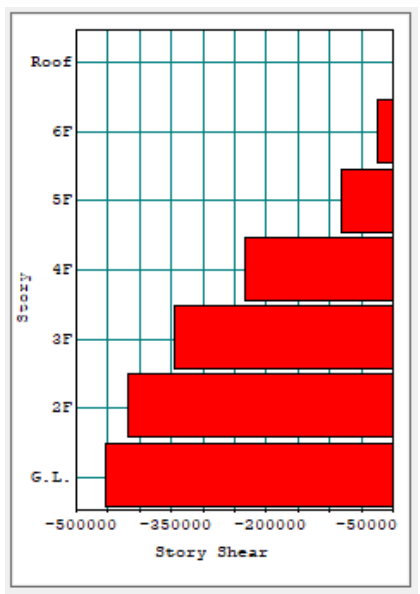

Gambar 7. Beban geser dasar seismik (EI-XN), kg

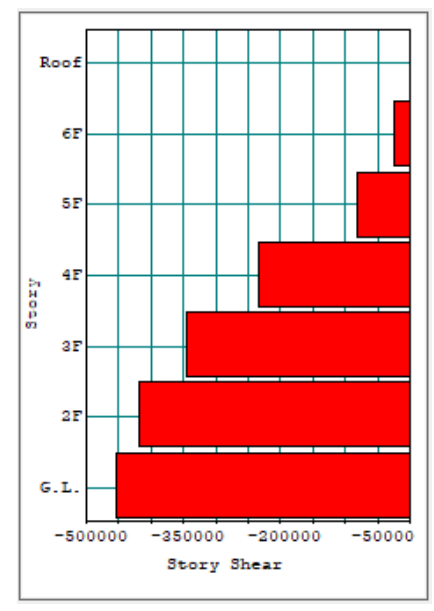

Gambar 8. Beban geser dasar seismic (EI-YN), kg

\section{Pemodelan Struktur 3D}

Pemodelan struktur pada Bangunan Rusunawa Kota Kediri dilakukan dengan modeI 3D dengan menggunakan program Midas Gen 2019.

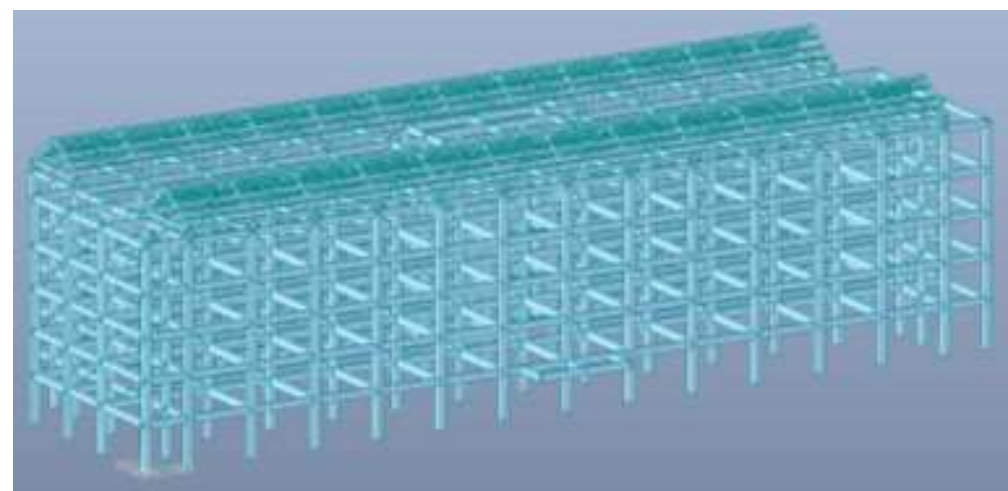

Gambar 9. Pemodelan struktur 3D Bangunan Rusunawa Kota Kediri

\section{Beban Mati Bangunan (DL)}

Beban mati pada Bangunan Rusunawa Kota Kediri terdiri dari: berat sendiri dari struktur tersebt, beban dinding, beban keramik, beban plafon dan penggantung plafon.

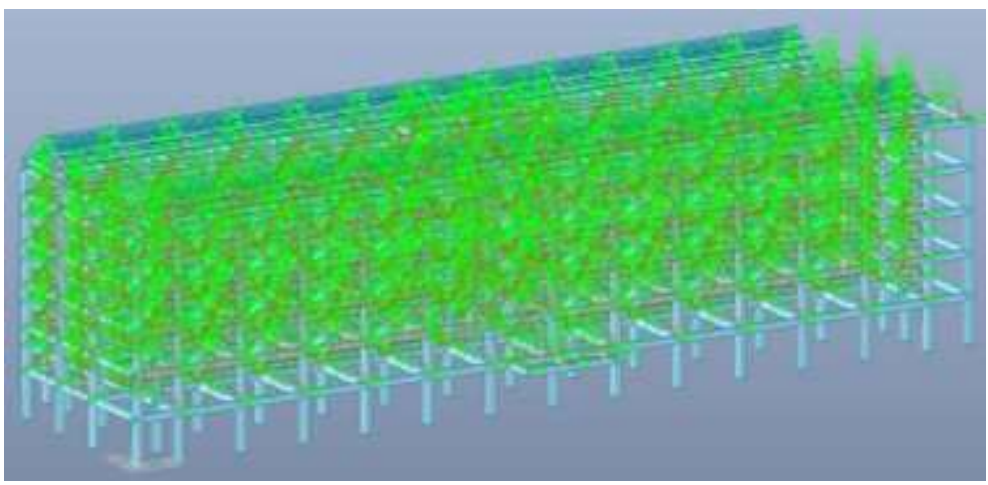

\section{Beban Hidup Bangunan (LL)}

Gambar 10. Beban mati pada Bangunan Rusunawa Kota Kediri

Beban hidup pada Bangunan Rusunawa Kota Kediri mengacu pada peraturan pembebanan SNI 1727:2013 Beban Minimum untuk Perencanaan Bangunan Gedung dan Struktur Iain, dimana acuan pembebanan menggunakan beban rumah tinggal apartemen. 


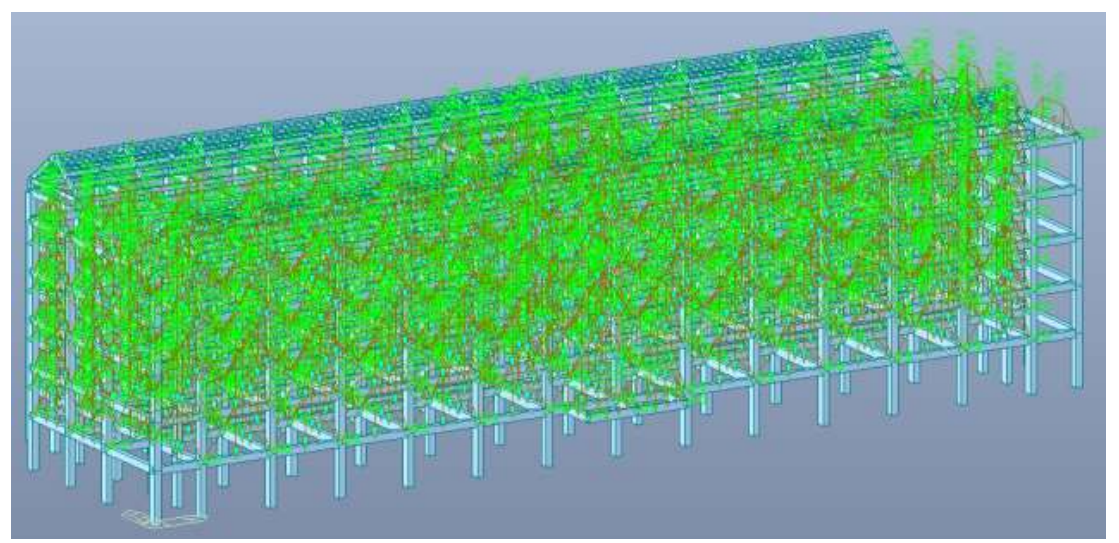

Gambar 11. Beban hidup pada Bangunan Rusunawa Kota Kediri

\section{Beban Angin pada Bangunan (WL)}

Beban angin pada Bangunan Rusunawa Kota Kediri mengacu pada peraturan pembebanan SNI 1727:2013 Beban Minimum untuk Perencanaan Bangunan Gedung dan Struktur Iain. Beban angin pada bangunan ini terdiri dari dua modeI pembebanan, beban angin arah Y (WI-Y) dan beban angina arah X (WI-X).

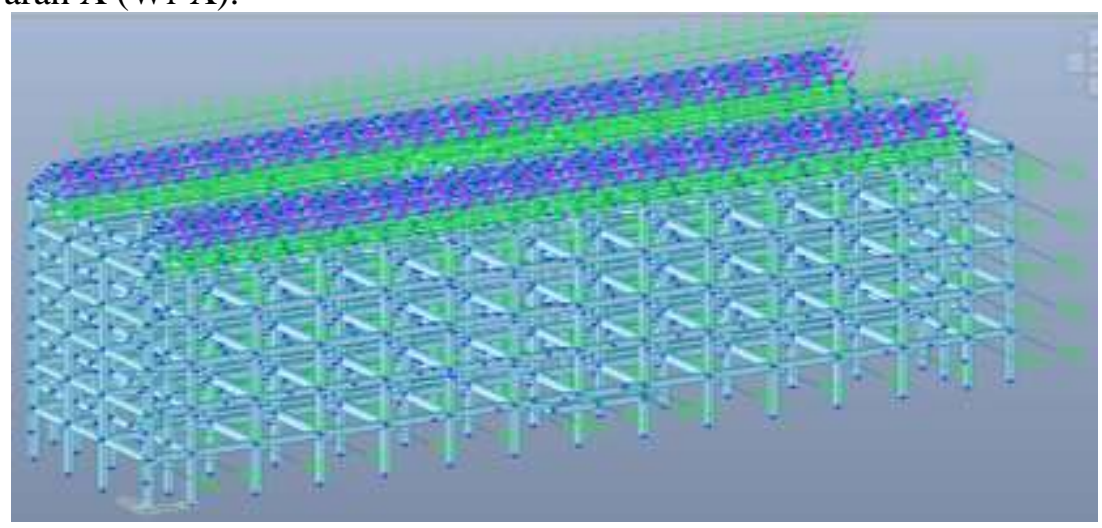

Gambar 12. Beban angin arah Y (WI-Y) pada Bangunan Rusunawa Kota Kediri

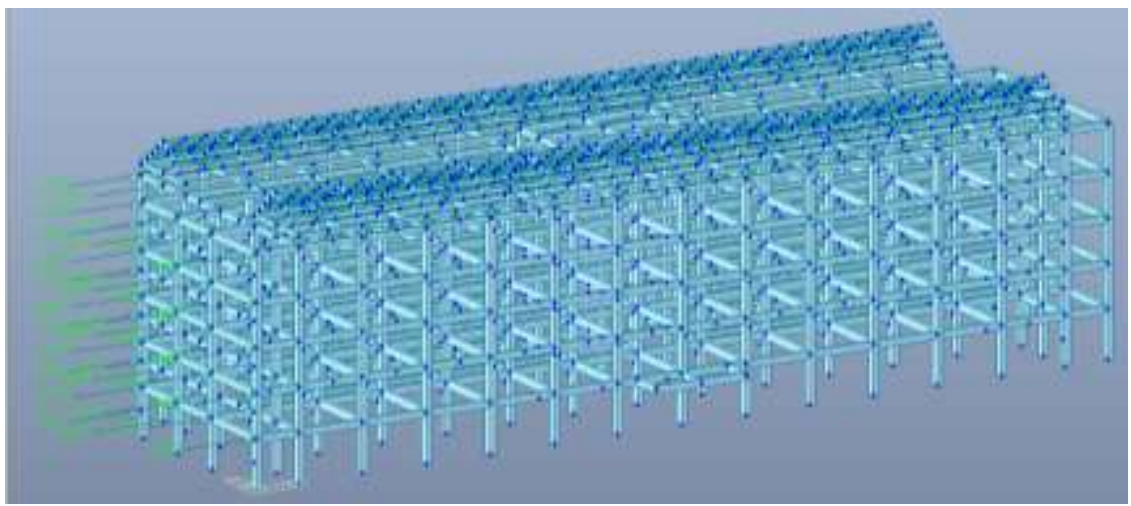

Gambar 13. Beban angin arah X (WI-X) pada Bangunan Rusunawa Kota Kediri

\section{Distribusi Gaya Gempa Latera pada Bangunan (EL)}

Gaya gempa lateraI statik ekivalen pada Bangunan Rusunawa Kota Kediri mengacu pada peraturan gempa SNI 1726:2012 Tata Cara Perencanaan Ketahanan Gempa untuk Struktur Bangunan Gedung dan Non Gedung. Beban gempa statik ekivalen pada bangunan ini terdiri dari empat modeI pembebanan, yaitu: beban gempa arah X positif (EI-XP), beban gempa arah X negatif (EI-XN), beban gempa arah Y positif (EI-YP), dan beban gempa arah Y negatif (EI-YN). 


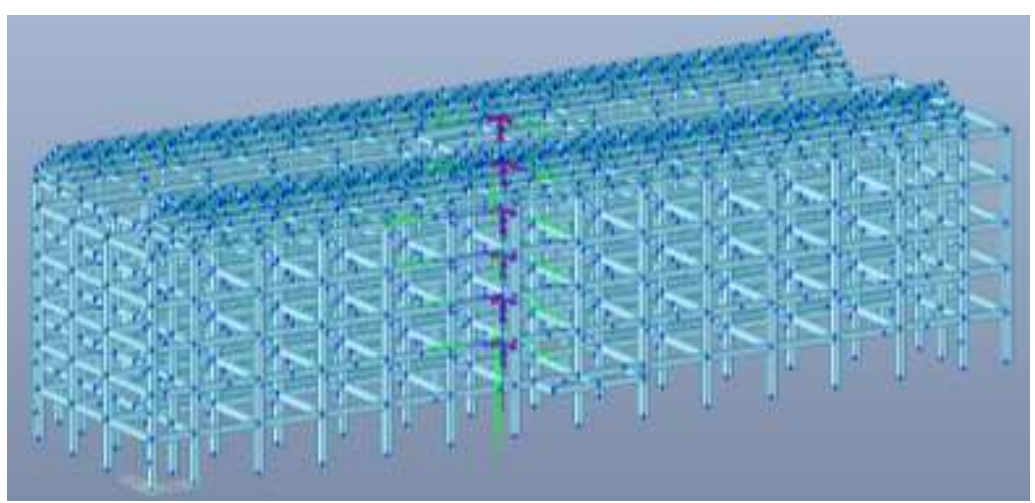

Gambar 14. Beban gempa arah X positif (EI-XP) pada Bangunan Rusunawa Kota Kediri

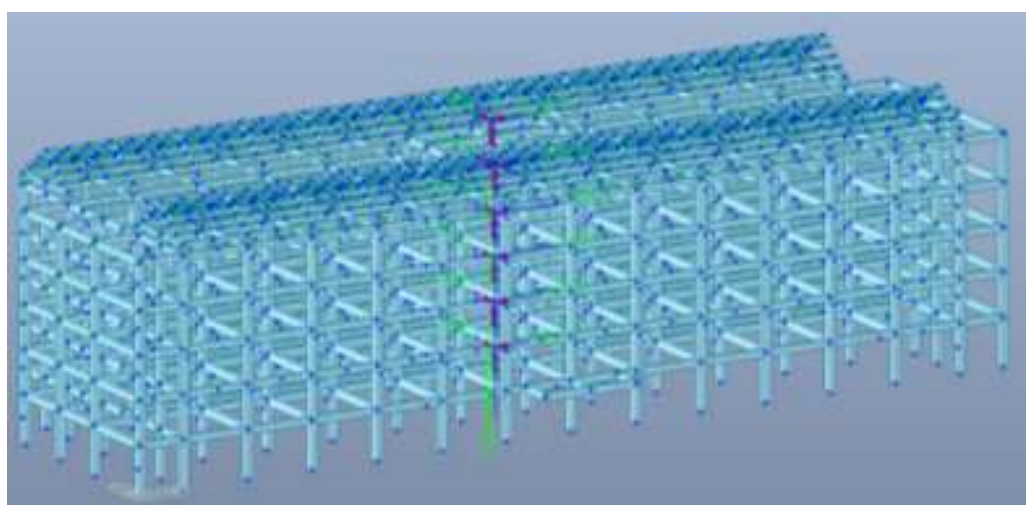

Gambar 15. Beban gempa arah X negatif (EI-XN) pada Bangunan Rusunawa Kota Kediri

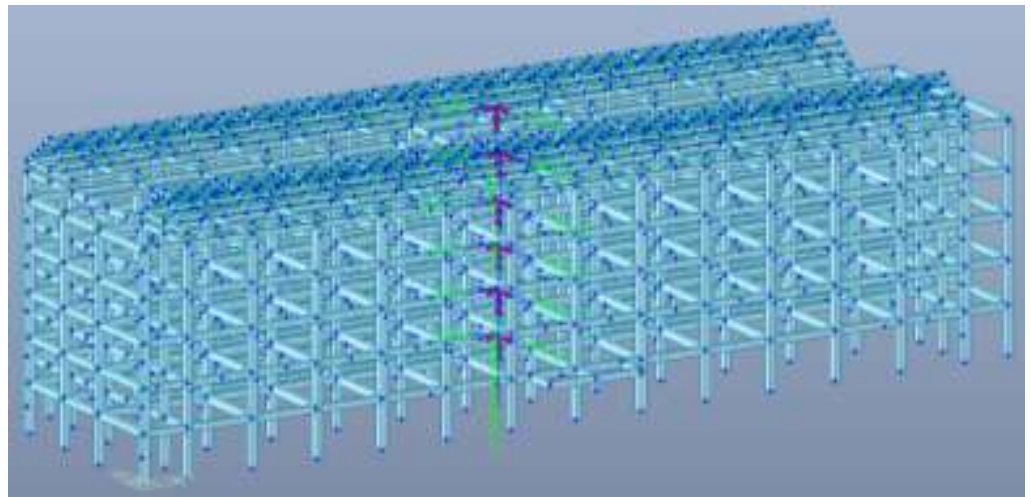

Gambar 16. Beban gempa arah Y positif (EI-YP) pada Bangunan Rusunawa Kota Kediri

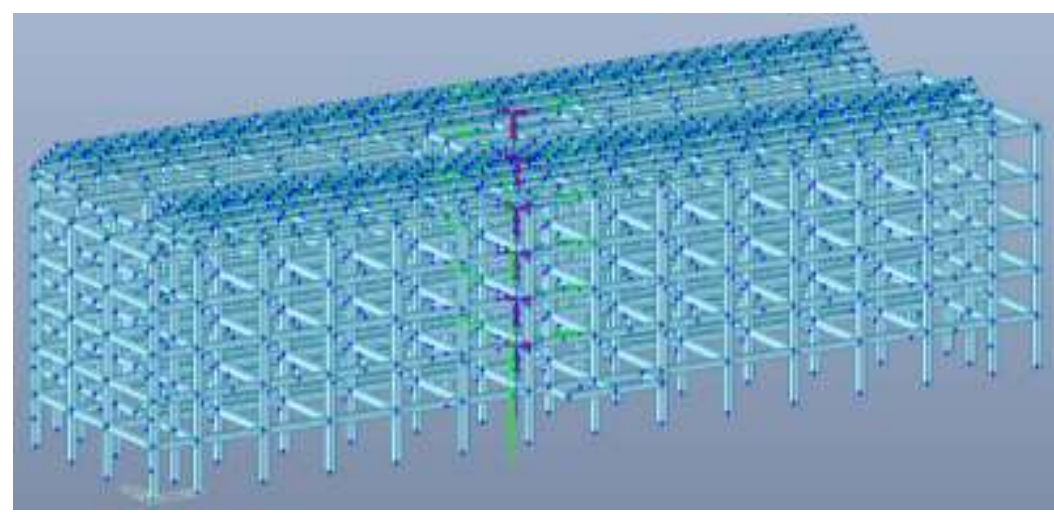

Gambar 17. Beban gempa arah Y negatif (EI-YN) pada Bangunan Rusunawa Kota Kediri 


\section{Mode Shape Akibat Beban Dinamis Response Spectrum}

Gaya gempa dinamis response spectrum pada Bangunan Rusunawa Kota Kediri mengacu pada peraturan gempa SNI 1726:2012 Tata Cara Perencanaan Ketahanan Gempa untuk Struktur Bangunan Gedung dan Non Gedung. Beban gempa dinamis response spectrum pada bangunan ini terdiri dari tiga modeI pembebanan, yaitu: beban gempa dinamis response spectrum arah $\mathrm{X}$ (RS:RX), beban gempa dinamis response spectrum arah Y (RS:RY), dan beban gempa dinamis response spectrum arah $\mathrm{Z}$ (RS:RZ).

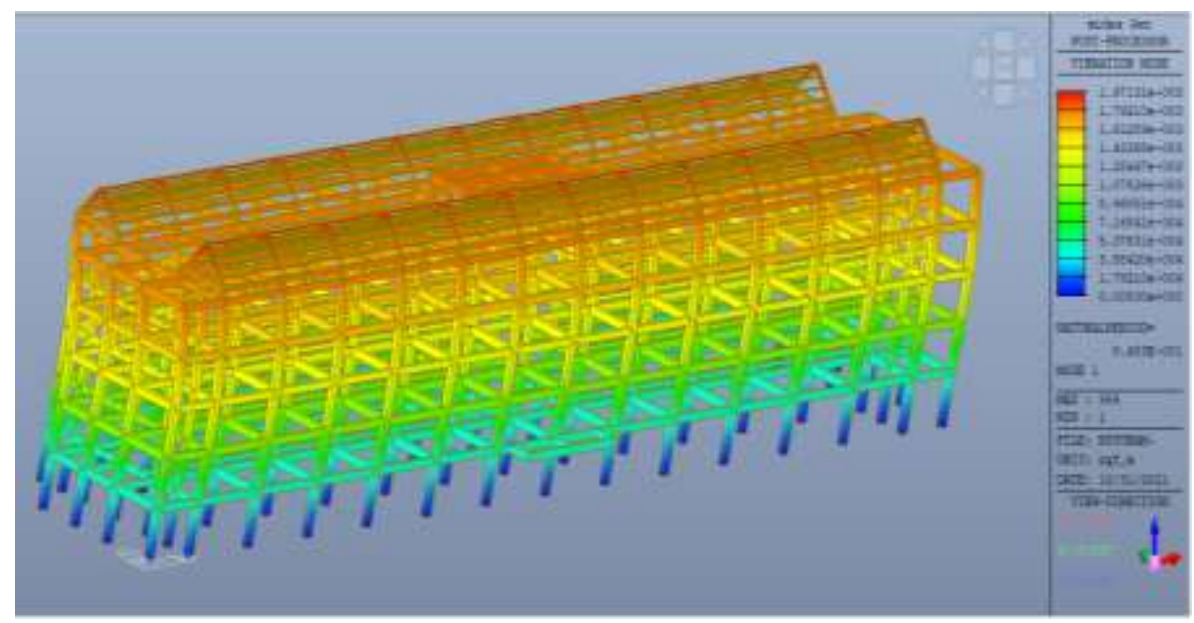

Gambar 18. Mode shape 1 beban dinamis response spectrum

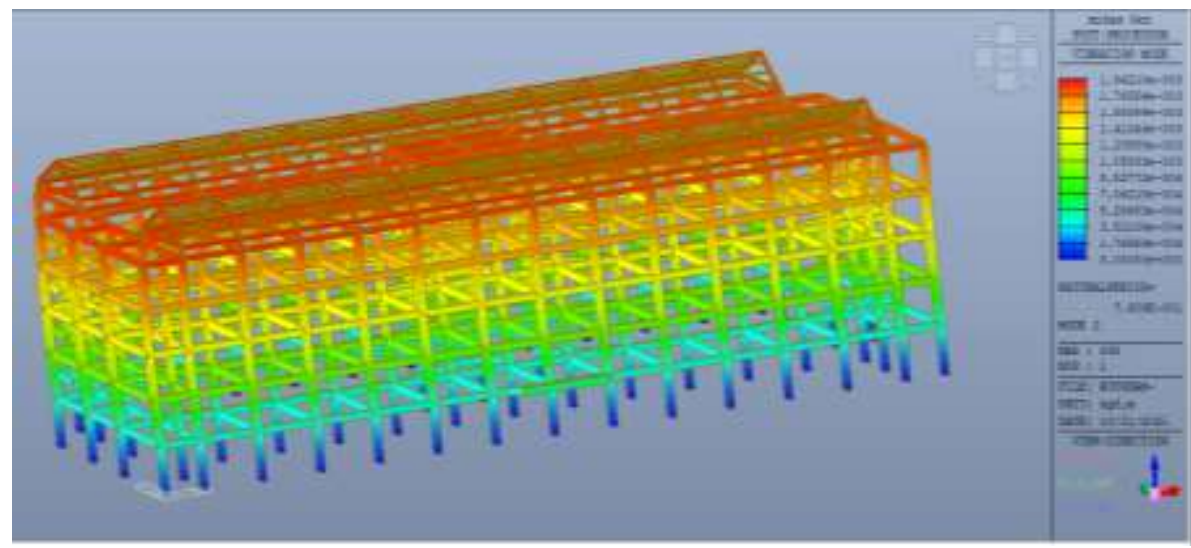

Gambar 19. Mode shape 2 beban dinamis response spectrum

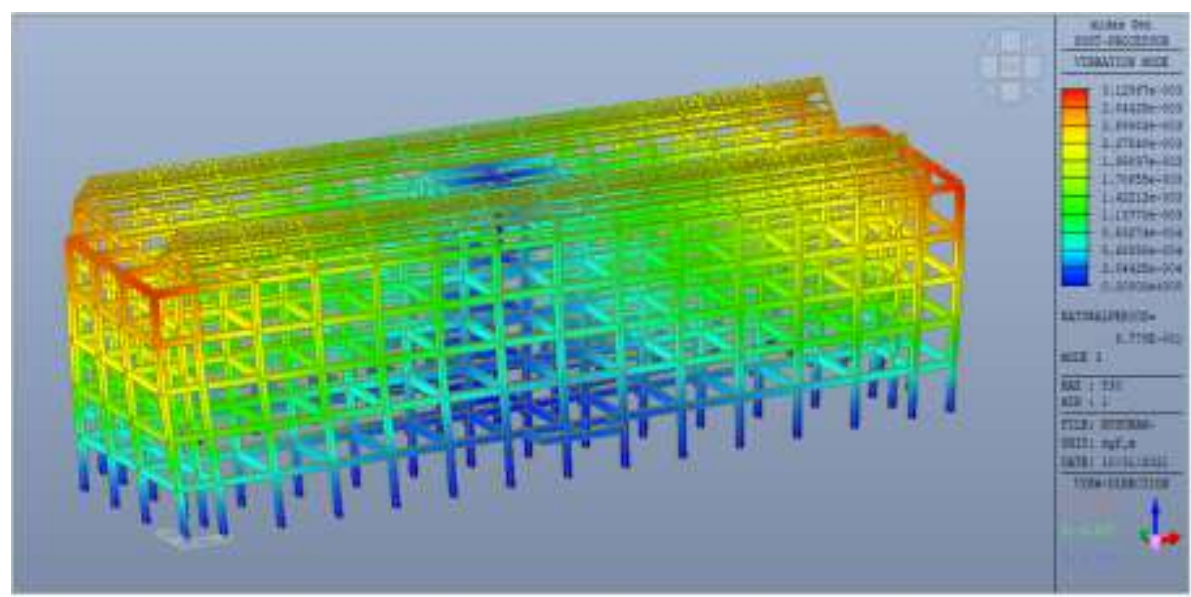

Gambar 20. Mode shape 3 beban dinamis response spectrum 


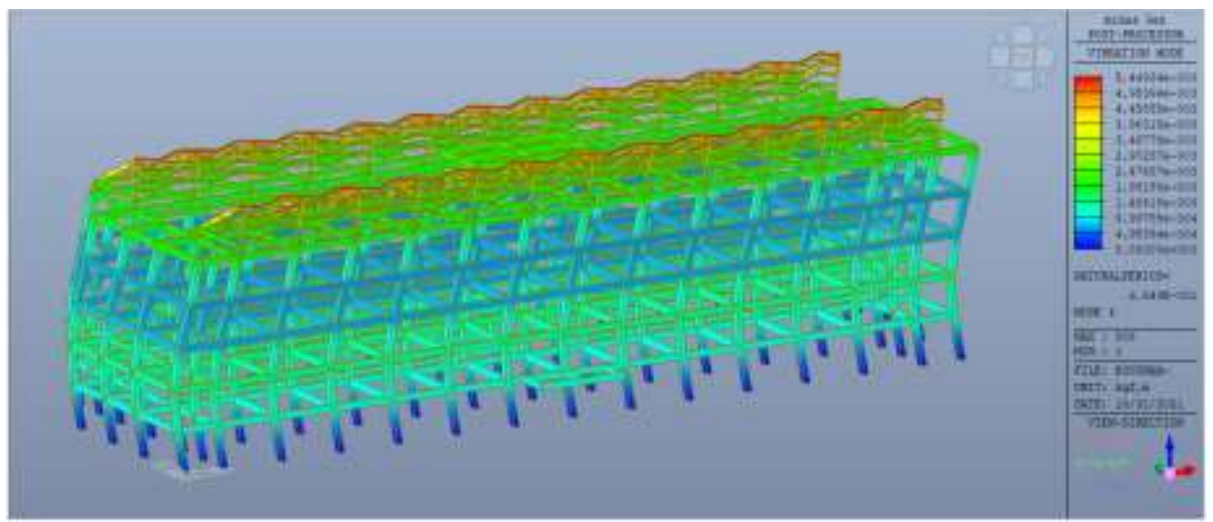

Gambar 21. Mode shape 4 beban dinamis response spectrum

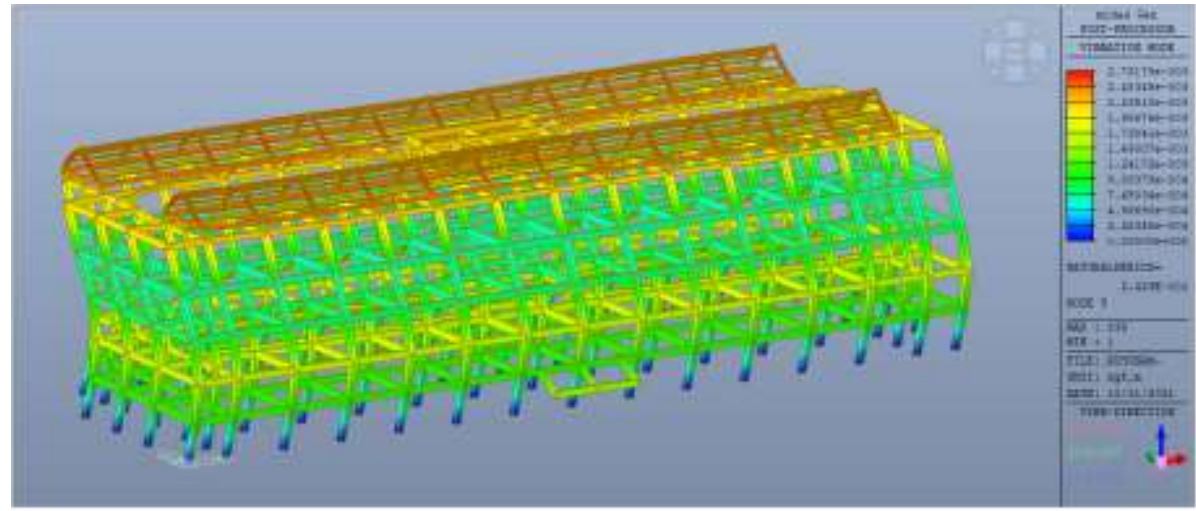

Gambar 22. Mode shape 5 beban dinamis response spectrum

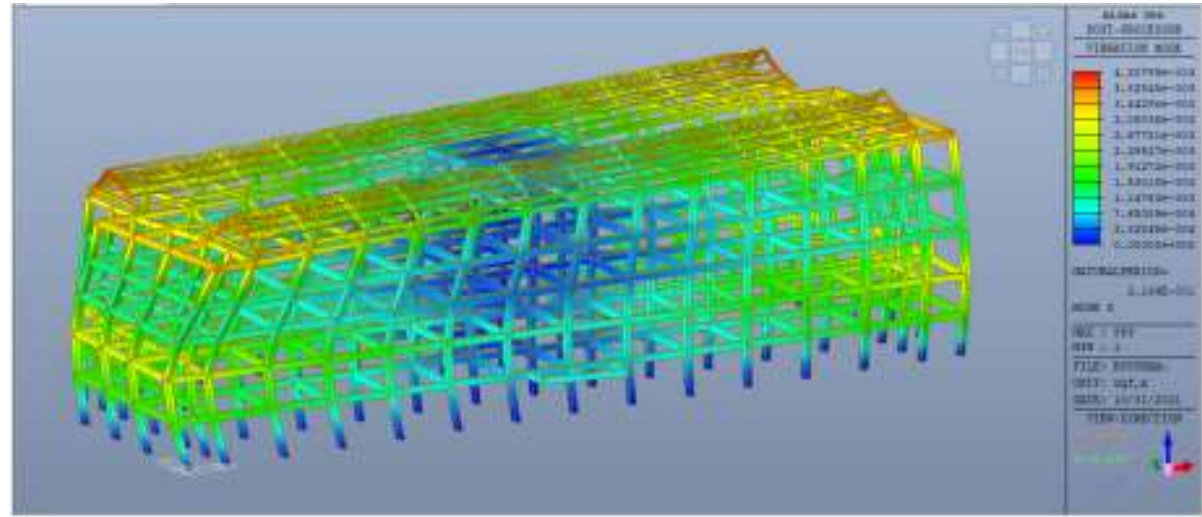

Gambar 23. Mode shape 6 beban dinamis response spectrum

\section{Desain Penulangan Balok dan Kolom}

Setelah melalui proses perencanaan pendimensian struktur dan kombinasi pembebanan, maka didapat hasiI perhitungan yaitu nilai momen, gaya geser, dan gaya aksial dari hasil perhitungan komputasi dengan menggunakan Midas Gen 2019.

Perencanakan penulangan balok digunakan hasil dari nilai momen maksimum, dan gaya geser yang terbesar dari portal melintang yang ditinjau berdasarkan hasil perhitungan Midas Gen tersebut. Nilai terbesar tersebut digunakan dengan anggapan bisa mewakili secara keseluruhan penulangan terbesar dari struktur balok tersebut.

Dari nilai momen dan gaya geser maksimum tersebut direncanakan dimensi tulangan dan jumlahnya. Dari parameter dimensi dan jumlah tulangan rencana tersebut akan dihitung nilai momen kapasitas balok. Apabila nilai momen dan gaya geser maksimum lebih kecil daripada 
momen dan geser kapasitasnya, maka struktur tersebut kuat menahan beban kombinasi yang bekerja.

Apabila momen dan gaya geser maksimum yang bekerja pada balok lebih besar daripada momen dan geser kapasitasnya, maka perlu perubahan pada pendimensian tulangan, jumlah tulangan, jarak sengkang, dan pendimensian balok tersebut.

Hasil perencanaan balok pada Bangunan Rusunawa Kota Kediri dapat dilihat pada tabeI 1 berikut ini.

Tabe1 Rekapitulasi kebutuhan tulangan Ientur dan geser pada balok

\begin{tabular}{|c|c|c|c|c|c|c|c|c|c|c|c|c|c|c|c|}
\hline \multicolumn{2}{|c|}{ Section } & $\mathrm{fc}^{\prime}$ & \multirow[b]{2}{*}{ POS } & \multirow[b]{2}{*}{$N(-)$ M_Ed } & \multirow[b]{2}{*}{ LCB } & \multirow[b]{2}{*}{ AsTop } & \multirow[b]{2}{*}{ Rebar } & \multirow[b]{2}{*}{$\mathrm{P}(+) \mathrm{M}$ E Ed } & \multirow[b]{2}{*}{ LCB } & \multirow[b]{2}{*}{ AsBot } & \multirow[b]{2}{*}{ Rebar } & \multirow[b]{2}{*}{ V_Ed } & \multirow[b]{2}{*}{ LCB } & \multirow[b]{2}{*}{ Asw } & \multirow[b]{2}{*}{ Stirrup } \\
\hline $\mathrm{Bc}$ & $\mathrm{Hc}$ & $\begin{array}{l}\text { fy_u } \\
\text { fy_s }\end{array}$ & & & & & & & & & & & & & \\
\hline \multicolumn{2}{|c|}{ B1 30/55 } & 29.1 & 1 & 250000000 & 11 & 100 & 3-P20 & 130000000 & 11 & 017.3 & 4-P13 & 202707 & 25 & 2368.2 & 2-P10@60 \\
\hline \multirow[b]{2}{*}{300} & \multirow{2}{*}{550} & 390 & $\mathrm{M}$ & 63000000 & 11 & 600.4 & 3-P16 & 91000000 & 11 & 02.08 & 3-P16 & 99059 & 25 & 1110.3 & 140 \\
\hline & & 240 & \rfloor & 250000000 & 15 & 1884.1 & $4-2-P 20$ & 110000000 & 15 & 81.41 & A-3-P13 & 196484 & 19 & 280.5 & 2-P10@60 \\
\hline \multirow{2}{*}{\multicolumn{2}{|c|}{ B2 35/45 }} & 29.1 & $I$ & 190000000 & 11 & 1810.9 & $5-1-P 20$ & 150000000 & \begin{tabular}{|l|l|}
37 \\
\end{tabular} & 1397.5 & 5-2-P16 & 331312 & 25 & 4703.8 & 2-P10@30 \\
\hline & & 390 & $M$ & 110000000 & 11 & 998.87 & 5-P16 & 86000000 & 15 & 719.64 & 6-P13 & 327678 & 25 & 4652.2 & @30 \\
\hline 350 & 450 & 240 & 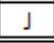 & 180000000 & 15 & 1751.8 & 5-4-P16 & 150000000 & 33 & 1366 & 5-2-P16 & 330746 & 25 & 4695.8 & 2-P10@30 \\
\hline \multicolumn{2}{|c|}{ B3 $35 / 45$} & 29.1 & 1 & 150000000 & 10 & 1414.1 & $6-5-P 13$ & 840000000 & 36 & 701.57 & 6-P13 & 286093 & 25 & 4257.9 & 2-P10@30 \\
\hline \multirow{2}{*}{350} & \multirow{2}{*}{450} & 390 & $\mathrm{M}$ & 110000000 & 8 & 999.78 & 5-P16 & 66000000 & 14 & 573.11 & 3-P16 & 275531 & 25 & 3911.9 & 2-P10@40 \\
\hline & & 240 & $」$ & 150000000 & 14 & 1426.3 & $6-5-P 13$ & 83000000 & 32 & 690.49 & 6-P13 & 286118 & 25 & 4258.3 & 2-P10@30 \\
\hline \multicolumn{2}{|c|}{ B4 25/45 } & 29.1 & $I$ & 49000000 & 10 & 416.79 & 3-1-P13 & 25000000 & \begin{tabular}{|l|}
10 \\
\end{tabular} & 409.36 & 3-1-P13 & 48853 & 115 & 2013.8 & 2-P10@70 \\
\hline & & 390 & $\mathrm{M}$ & 13000000 & 14 & 409.36 & 3-1-P13 & 000 & 3 & 09.36 & 13 & 8380 & 25 & .02 & 270 \\
\hline 230 & $4=$ & 240 & \rfloor & 51000000 & 14 & 436.42 & 3-1-P13 & 26000000 & \begin{tabular}{|l|l|}
14 & \\
\end{tabular} & 409.36 & 3-1-P13 & 48783 & 71 & 2013.8 & $@ 70$ \\
\hline 85 & 45 & 29.1 & 1 & 25000000 & 9 & 409.36 & 3-1-P13 & 20000000 & 13 & 409.36 & 3-1-P13 & 48829 & 93 & 2013.8 & $\$ 70$ \\
\hline 250 & 450 & 390 & $\mathrm{M}$ & 11000000 & 12 & 409.36 & 3-1-P13 & 000 & 13 & 409.36 & 3-1-P13 & 80592 & 25 & 1173.9 & 130 \\
\hline 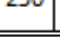 & 450 & 240 & 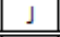 & 26000000 & 13 & 409.36 & 3-1-P13 & 18000000 & 9 & 409.36 & 3-1-P13 & 48822 & 93 & 2013.8 & $\$ 70$ \\
\hline 05 & 45 & 29.1 & 1 & 28000000 & 10 & 409.36 & 3-1-P13 & 000 & \begin{tabular}{|l|l|}
10 \\
\end{tabular} & 409.36 & 3-1-P13 & 46030 & 115 & 2013.8 & 70 \\
\hline & & 390 & $\mathrm{M}$ & 6892945 & 10 & 409.36 & 3-1-P13 & 000 & 1 & 409.36 & 3-1-P13 & 35461 & 25 & 573.02 & 270 \\
\hline 250 & 450 & 240 & $J$ & 27000000 & 14 & 409.36 & 3-1-P13 & 14000000 & 14 & 409.36 & 3-1-P13 & 46243 & 115 & 2013.8 & 2-P10@70 \\
\hline B63 & $0 / 60$ & 29.1 & 1 & 91000000 & 13 & 654.98 & 4-1-P13 & 58000000 & 3 & 654.98 & 4-1-P13 & 483836 & 25 & 4978.7 & 2-P10@30 \\
\hline & 60 & 390 & $\mathrm{M}$ & 49000000 & 13 & 654.98 & 4-1-P13 & 48000000 & 15 & 654.98 & 4-1-P13 & 479309 & 25 & 4932.1 & 2-P10@30 \\
\hline 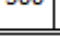 & . & 240 & $」$ & 87000000 & 9 & 654.98 & 4-1-P13 & 61000000 & 1 & 654.98 & 4-1-P13 & 483244 & 25 & 4972.6 & 2-P10@30 \\
\hline . & 年 & 29.1 & 1 & 110000000 & 1 & 1045 & 4-4-P13 & 57000000 & 1 & 491.23 & 4-P13 & 190336 & 25 & 2846.5 & 2-P10@50 \\
\hline & 450 & 390 & $\mathrm{M}$ & 81000000 & 1 & 707.73 & 4-2-P13 & 28000000 & 1 & 491.23 & 4-P13 & 181082 & 25 & 2660.8 & 2-P10@50 \\
\hline 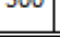 & 450 & 240 & $J$ & 110000000 & 3 & 1044.8 & 4-4-P13 & 57000000 & 3 & 491.23 & 4-P13 & 190361 & 25 & 2846.9 & 2-P10@50 \\
\hline 0 & 35 & 29.1 & 1 & \begin{tabular}{|l|}
57000000 \\
\end{tabular} & 1 & 793.38 & 2-2-P16 & 29000000 & 1 & 360.47 & 2-1-P13 & 38642 & 1 & 2013.8 & 2-P10@70 \\
\hline & 35 & 390 & $\mathrm{M}$ & 40000000 & 3 & 521 & 2-2-P13 & 140000000 & 3 & 254.71 & 2-P13 & 86419 & 25 & 1797.3 & 80 \\
\hline & 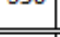 & 240 & $」$ & 58000000 & 3 & 793.52 & 2-2-P16 & 29000000 & 3 & 360.47 & 2-1-P13 & 38641 & 3 & 2013.8 & 2-P10@70 \\
\hline RB1 & 40 & 29.1 & I & 43000000 & 13 & 422.57 & 3-1-P13 & 27000000 & 15 & 363.88 & 3-P13 & 41941 & 115 & 2013.8 & 2-P10@70 \\
\hline & 40 & 390 & $\mathrm{M}$ & 18000000 & 13 & 363.88 & 3-P13 & 17000000 & 13 & 363.88 & 3-P13 & 53474 & 25 & 875.99 & 2-P10@170 \\
\hline 200 & & 240 & 1 & 34000000 & 15 & 363.88 & 3-P13 & 30000000 & 13 & 363.88 & 3-P13 & 42177 & 47 & 2013.8 & 2-P10@70 \\
\hline & $\rightarrow$ & 29.1 & 1 & 29000000 & 10 & 363.88 & 3-P13 & 14000000 & 10 & 363.88 & 3-P13 & 40995 & 25 & 2013.8 & 2-P10@70 \\
\hline 25 & $A 0$ & 390 & $\mathrm{M}$ & 9748971 & 10 & 363.88 & 3-P13 & 11000000 & 10 & 363.88 & 3-P13 & 26875 & 25 & 644.43 & 2-P10@240 \\
\hline 200 & 400 & 240 & 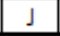 & 29000000 & 14 & 363.88 & 3-P13 & 15000000 & \begin{tabular}{|l|l}
14 \\
\end{tabular} & 363.88 & 3-P13 & 40956 & 25 & 2013.8 & 2-P10@70 \\
\hline
\end{tabular}

Keterangan:

$\mathrm{Bc}$

$\mathrm{Hc}$

fc'

fy_u

fy_s

$\mathrm{PoS}$

N(-) M_Ed

$\mathrm{P}(+)$ M_Ed

V_Ed

ICB

AsTop

AsBot

Asw
$=$ Iebar balok $(\mathrm{mm})$

$=$ Tinggi balok $(\mathrm{mm})$

$=$ Mutu beton $(\mathrm{MPa})$

$=$ Mutu tulangan utama $(\mathrm{MPa})$

$=$ Mutu tulangan sengkang $(\mathrm{MPa})$

= Ietak yang ditinjau ( $\mathrm{I}=$ ujung I balok; $\mathrm{M}=$ tengah balok; $\mathrm{J}=$ ujung $\mathrm{J}$ balok)

$=$ Momen negatif paling besar dari berbagai kombinasi pembebanan (N.mm)

$=$ Momen positif paling besar dari berbagai kombinasi pembebanan (N.mm)

= Gaya geser paling besar dari berbagai kombinasi pembebanan $(\mathrm{N})$

$=$ Nomor kombinasi pembebanan

$=$ Kebutuhan Iuas tulangan bagian atas $\left(\mathrm{mm}^{2}\right)$

$=$ Kebutuhan Iuas tulangan bagian bawah $\left(\mathrm{mm}^{2}\right)$

$=$ Kebutuhan Iuas tulangan sengkang $\left(\mathrm{mm}^{2}\right)$ 
Rebar = Tulangan utama yang digunakan

Stirrup $\quad=$ Tulangan sengkang yang digunakan

Sama haInya dengan struktur balok, perencanaan struktur kolom juga melakukan tahap yang sama, dari perencanaan pendimensian struktur dan kombinasi pembebanan, maka didapat hasiI perhitungan yaitu nilai momen, gaya geser, dan gaya aksial dari hasil perhitungan komputasi dengan menggunakan Midas Gen 2019.

Dari nilai momen, gaya geser, dan aksial maksimum tersebut direncanakan dimensi tulangan dan jumlahnya. Dari parameter dimensi dan jumlah tulangan yang direncanakan tersebut akan dihitung nilai momen kapasitas. Apabila nilai momen, gaya geser, dan gaya aksial maksimum lebih kecil daripada momen, aksial, dan geser kapasitasnya, maka struktur tersebut kuat menahan beban kombinasi yang bekerja. Apabila gaya momen, gaya geser, dan aksial maksimum Iebih besar daripada momen, aksial, dan geser kapasitasnya, maka perlu perubahan pada pendimensian tulangan, jumlah tulangan, jarak sengkang, dan pendimensian kolom tersebut.

Hasil perencanaan kolom pada Bangunan Rusunawa Kota Kediri dapat dilihat pada tabeI 2 berikut ini.

Tabe 1 Rekapitulasi kebutuhan tulangan Ientur dan geser pada kolom

\begin{tabular}{|c|c|c|c|c|c|c|c|c|c|c|c|c|c|c|c|c|}
\hline \multicolumn{2}{|c|}{ Section } & $\mathrm{fe}^{\prime}$ & fy_u & \multirow{2}{*}{$1 C B$} & \multirow{2}{*}{$\frac{\text { N_Ed }}{\text { Rat }-N}$} & \multirow{2}{*}{$\begin{array}{l}\text { M_Ed } \\
\text { Rat-M }\end{array}$} & \multirow{2}{*}{ Ast } & \multirow{2}{*}{ V-Rebar } & \multirow{2}{*}{ LCB } & \multirow{2}{*}{$\frac{V_{\text {V_Ed.end }}}{\mathrm{V} \text { V_Ed.mid }}$} & \multirow{2}{*}{$\begin{array}{l}\text { Rat-V.end } \\
\text { Rat-V.mid }\end{array}$} & \multirow{2}{*}{$\frac{\text { Asw-H.end }}{\text { Asw-H.mid }}$} & \multirow{2}{*}{$\begin{array}{l}\text { H-Rlebar,end } \\
\text { H-Robar,mid }\end{array}$} & \multirow{2}{*}{$\begin{array}{l}\text { Vjhed } \\
\text { Rats }\end{array}$} & \multirow{2}{*}{ Ash } & \multirow{2}{*}{ 4-Mebar } \\
\hline Bc & $\mathrm{Hc}$ & Height & $f y=s$ & & & & & & & & & & & & & \\
\hline 550 & 400 & 2800 & 240 & 103 & 0.927 & 0.919 & 5655 & $18-5-920$ & 99 & 122 & 879 & 1.2 & $2 \cdot P$ & 1 & 9894.64 & $2-63910$ \\
\hline 550 & 400 & 2800 & 240 & 98 & 0.909 & 0.891 & 3450 & $26-6-P_{13}$ & 104 & 230656 & 0.957 & 2506.2 & $2+10 \oplus 60$ & 0.993 & 4481.66 & $2-29 P 10$ \\
\hline \multicolumn{2}{|c|}{$\times 340 / 55$} & 29.1 & 390 & \multirow{2}{*}{100} & 177544 & $3.7 E=08$ & \multirow{2}{*}{5890} & \multirow{2}{*}{$12-4-925$} & 105 & 238224 & 0.824 & 3141.6 & $2+13$ DSD & 1029740 & \multirow{2}{*}{5185.95} & \multirow{2}{*}{$2-34913$} \\
\hline$\$ 50$ & 400 & 28000 & 240 & & 0.973 & 0.951 & & & 105 & 257668 & 0.891 & 2799.7 & 2.P10 050 & 0.987 & & \\
\hline
\end{tabular}

Keterangan:

\begin{tabular}{|c|c|}
\hline $\mathrm{Bc}$ & $=$ lebar kolom $(\mathrm{mm})$ \\
\hline $\mathrm{Hc}$ & $=$ Tinggi $\operatorname{kolom}(\mathrm{mm})$ \\
\hline $\mathrm{fc}^{\prime}$ & $=$ Mutu beton $(\mathrm{MPa})$ \\
\hline fy_u & $=$ Mutu tulangan utama $(\mathrm{MPa})$ \\
\hline fy_s & $=$ Mutu tulangan sengkang $(\mathrm{MPa})$ \\
\hline N_Ed & $=$ Gaya aksiaI paling besar dari berbagai kombinasi pembebanan $(\mathrm{N})$ \\
\hline Rat-N & $=$ Rasio antara gaya aksial dan kapasitas aksial kolom \\
\hline M Ed & $=$ Momen positif paling besar dari berbagai kombinasi pembebanan (N.mm) \\
\hline Rat-M & $=$ Rasio antara momen dan kapasitas momen kolom \\
\hline Ast & $=$ Kebutuhan Iuas tulangan utama kolom $\left(\mathrm{mm}^{2}\right)$ \\
\hline V-Rebar & $=$ Tulangan utama yang digunakan \\
\hline V_Ed.end & $=$ Gaya geser ujung paling besar dari berbagai kombinasi pembebanan $(\mathrm{N})$ \\
\hline V_Ed.mid & $=$ Gaya geser paling besar dari berbagai kombinasi pembebanan $(\mathrm{N})$ \\
\hline Rat-V.end & $=$ Rasio antara geser dan kapasitas geser sengkang pada ujung kolom \\
\hline Rat-V.mid & $=$ Rasio antara geser dan kapasitas geser sengkang pada tengah kolom \\
\hline Asw-H.end & $=$ Kebutuhan Iuas tulangan sengkang pada ujung kolom $\left(\mathrm{mm}^{2}\right)$ \\
\hline Asw-H.mid & $=$ Kebutuhan Iuas tulangan sengkang pada tengah kolom $\left(\mathrm{mm}^{2}\right)$ \\
\hline H-Rebar.end & $=$ Tulangan sengkang yang digunakan pada ujung kolom \\
\hline H-Rebar.mid & $=$ Tulangan sengkang yang digunakan pada tengah kolom \\
\hline ICB & $=$ Nomor kombinasi pembebanan \\
\hline Vjhd & $=$ Gaya geser pada joint balok-kolom $(\mathrm{N})$ \\
\hline Rat-J & $=$ Rasio antara geser dan kapasitas geser pada joint balok-kolom \\
\hline Ash & $=$ Kebutuhan Iuas tulangan pada joint balok-kolom $\left(\mathrm{mm}^{2}\right)$ \\
\hline J-Rebar & $=$ Tulangan yang digunakan pada joint balok-kolom \\
\hline
\end{tabular}




\section{Kontro terhadap Strong Column Weak Beam}

Penerapan metode strong column weak beam pada Bangunan Rusunawa Kota Kediri bertujuan agar bangunan memiliki ketahanan yang cukup baik ketika menerima beban gempa. Setelah balok dan kolom direncanakan maka harus dikontroI rasio perbandingan antara kapasitas kolom dengan kapasitas balok, rasio perbandingan antara kapasitas kolom dengan balok harus lebih dari atau sama dengan 1,3. Apabila persyaratan rasio tersebut terpenuhi maka sudah memenuhi perilaku strong column weak beam, apabila tidak terpenuhi maka perencanaan kolom harus dirubah untuk diperoleh kapasitas kolom yang lebih besar.

KontroI terhadap perilaku strong column weak beam pada Bangunan Rusunawa Kota Kediri dapat dilihat pada gambar 23 berikut ini.

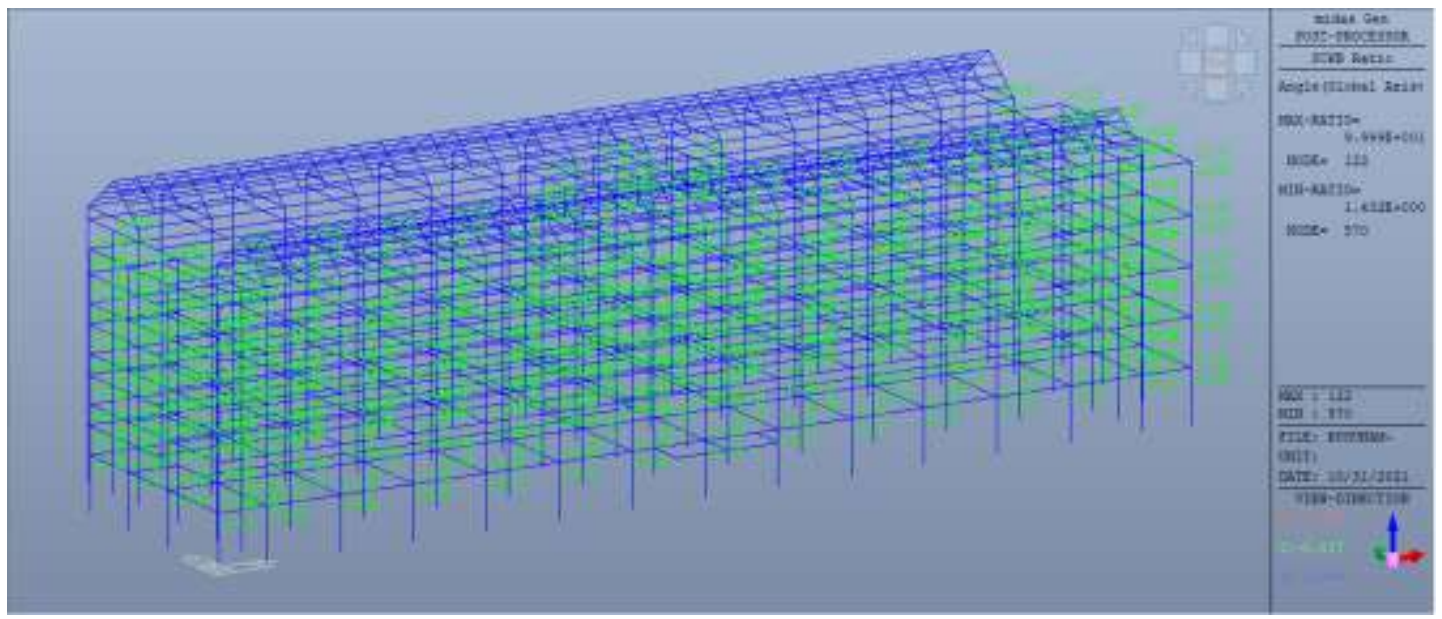

Gambar 24. KontroI terhadap perilaku strong column weak beam pada Bangunan Rusunawa Kota Kediri

\section{KESIMPULAN DAN SARAN}

Dari hasil perhitungan dan pembahasan, didapatkan kesimpulan bahwa pada perencanaan ulang Bangunan Rusunawa Kota Kediri yang menggunakan sistem rangka beton bertulang pemikuI momen khusus yang mengacu pada peraturan gempa SNI 1726:2012 dan sistem strong column weak beam dipilih sebagai alternatif desain untuk memperhitungkan bahwa gedung tersebut juga dapat menerima gaya lateral yang diakibatkan oleh gempa yang dikombinasikan dengan peraturan struktur beton SNI 2847:2013. Pemilihan sistem rangka beton bertulang pemikuI momen khusus dan sistem strong column weak beam sebagai alternatif desain bangunan juga menghasilkan gedung yang kuat dan aman karena gaya lateral dapat ditahan dengan baik oleh rangka beton bertulang.

Perencanaan ulang ini melakukan perubahan pada desain struktur balok dan kolom. HaI ini dikarenakan struktur eksisting Bangunan Rusunawa Kota Kediri kurang mampu menahan gaya Iateral yang diakibatkan beban gempa yang mengacu pada SNI 1726:2012, selain itu struktur eksisting bangunan itu juga tidak memenuhi penerapan sistem strong column weak beam.

Perlu kiranya dilakukan kajian untuk melakukan perkuatan pada Bangunan Rusunawa Kota Kediri, hal ini ditujukan agar bangunan tersebut mampu menahan gaya lateral yang diakibatkan beban gempa yang mengacu pada SNI 1726:2012 dan dapat memenuhi penerapan sistem strong column weak beam. 


\section{DAFTAR PUSTAKA}

Akbar, FarisaI. 2019. Filosofi Bangunan Tahan Gempa From https://farisal.com/filosofi-bangunantahan-gempa, 28 November 2019.

ATC-33 Project. 1997. FEMA 273 - NEHRP Guidelines For The Seismic Rehabilitation Of Building. Washington, D.C.: Building Seismic Safety Council.

Direktorat Penyelidikan Masalah Bangunan. 1983. Peraturan Pembebanan Indonesia untuk Gedung. Bandung : Yayasan Iembaga Penyelidikan Masalah Bangunan.

Nawi, Edward G. 1990. Beton Bertulang Suatu Pendekatan Dasar. Bandung : Eresco.

Praja, Baskoro Abdi. 2020. Penerapan Sistem "Strong Column and Weak Beam" pada Struktur Bangunan. From https://eticon.co.id/strong-column-and-weak-beam, 2 April 2020.

Purwono, Rachmat. 2005. Perencanaan Struktur Beton Bertulang Tahan Gempa, Edisi Kedua Surabaya : ITS.

Standar NasionaI Indonesia 1726-2012. 2012. Tata Cara Perencanaan Ketahanan Gempa Untuk Struktur Bangunan Gedung dan non-Gedung. Jakarta : Badan Standarisasi NasionaI.

Standar NasionaI Indonesia 2847-2013. 2013. Persyaratan beton struktural untuk bangunan gedung. Jakarta : Badan Standarisasi Nasional.

Standar NasionaI Indonesia 1727-2013. 2013. Beban Minimum untuk Perancangan Bangunan Gedung dan Struktur Iain. Jakarta : Badan Standarisasi NasionaI. 